\title{
Work and Community ${ }^{1}$
}

\author{
Richard H. Price ${ }^{2}$ \\ University of Michigan
}

Work can affect psychological well being, one's sense of personal identity, and provide a psychological sense of community. Work today is a major locus of social change and a reflection of our social values. Work and community are not separate domains, but are interconnected and interdependent. The possible sources of the psychological sense of the community at work are considered. Then influences flowing from work to family and community, including emotional spillover, indirect socialization, and the effects of workplace participation are discussed. Contemporary changes in families and communities suggest needed shifts in the boundary between work and fami$l y$, the allocation of work, and even its definition.

I would like to propose that community psychologists consider work and the connection between work and community as an important and exciting domain for research and action. The experience of work and the interrelationship between work and community touch on the major themes and preoccupations of our field. Work is a potential source of psychological well being, identity, and psychological sense of community. It is now a locus of dramatic social change and it is an expression of our social values as well. Finally, work and community are interconnected in important ways that we are only beginning to understand. Let me be more specific.

\section{WORK AND COMMUNITY PSYCHOLOGY}

As community psychologists we share an enduring concern about the psychological life of individuals and groups. And work is consequential for

\footnotetext{
'This article is based on the Presidential Address for Division 27, Community Psychology, of the American Psychological Association, Toronto, Canada, August 26, 1984.

${ }^{2}$ All correspondence should be sent to Richard H. Price, Survey Research Center 2263, The University of Michigan, Ann Arbor, Michigan 48106.
} 
psychological well being. Jobs have characteristics that are important for psychological well being, including powerlessness or control, monotony or variety, overload and underutilization. We can think of each job as being located on these dimensions and we know, for example, that jobs that provide little personal control and exact heavy demands can produce considerable psychological distress (Kahn, 1981; Price, 1984c).

But work is important for other aspects of psychological life because work also confers identity on each of us. "When people ask that most selfidentifying of questions - Who am I? - They answer in terms of their occupation: tool maker, press operator, typist, doctor, construction worker, teacher. Even people who are not working identify themselves by their former work or their present wish for it, describe themselves as retired or unemployed" (Kahn, 1981, p. 11). For many of us, then, the kind of work we have - or don't have - is an eloquent, if silent, statement of who we think we are and what is meaningful to us.

So psychological life work is consequential both for well being and for identity. But for community psychologists there is still more relevance. The workplace itself can be a critical source of the psychological sense of community. Furthermore, we are beginning to learn something about how to enhance that sense of community and what the benefits can be both for individuals and for the group (Klein \& D'Aunno, in press). For community psychologists whose goal is the creation and enhancement of the sense of community, the workplace offers opportunities not yet taken.

While psychological identity, well being, and sense of community are all critical aspects of the experience of work and the workplace, work has also become a critical locus of social change. Let me describe some of the social changes that are transforming the world of work. Consider first some of the demographic changes. Women are entering the workplace in unprecedented numbers. Two decades ago, 23 million American women worked; today there are 48 million. Since 1960 there has been a $109 \%$ increase in the female work force, while the male work force has increased only $36 \%$. Perhaps even more important, in 1960 only $19 \%$ of women with children under 6 years old worked outside the home. In 1983, 50\% women with children under 6 years old worked full time outside the home (Robey \& Russell, 1984). These changes are transforming our earlier sense of the social institutions of family and work, and they are transforming our communities as well.

The economic changes too are profound. We are shifting from an industrial to a service economy, an economy that requires information skills rather than manual skills. At the same time, work is being transformed by technological change and workers are being displaced by the technology as well as being helped by it. In Detroit and southeastern Michigan where I live and work, thousands of auto workers are being replaced by robots and no 
work with the equivalent pay is available. How these workers see their life prospects and those of their children is not yet well understood. We do know that the families of displaced workers are experiencing considerable strain and that policies to buffer the strain lag far behind the need for them (Price, 1984a).

We are also experiencing significant changes in the organizational culture of work. Changes in power relationships in the workplace are occurring. There is increasing pressure for worker participation and control over the planning and conduct of work (Lawler, 1982). Hierarchical relationships are being replaced in some cases by more egalitarian work teams. These changes represent both opportunities and challenges, the impact of which is still unclear.

While work is psychologically significant and undergoing social change, it is also an expression of our social values. Our choices about the allocation of work, how it shall be compensated, and even whether an activity is perceived as work or not are actually expressions of our values and the values of our community. It is no surprise that questions of equal pay for equivalent work and the allocation of family and work roles should so preoccupy us in these times (Kamerman \& Hayes, 1982). These issues represent surface manifestations of profound stirrings in our value orientation and the ways in which we perceive our families, our work, and our communities.

But even while there are good psychological, social and value reasons for considering the relevance of work to community psychology, there is yet another reason to do so. It is that the issue of work has actually been there all along. After all, work life and community life are not separate domains, hermetically sealed off from one another. On the contrary, work and community life interpenetrate each other and stand in complex ecological relationship to one another. They are interdependent, mutually influencing life spheres (Bronfenbrenner, 1982; Crouter, 1984a; Piotrkowski, 1979). The experiences, pressures, constraints, and joys of each life sphere spill over into the other. There are multiple channels of influence connecting work life and community life. Furthermore, the influences flow in both directions: from work to family and community life; and in the reverse, from concerns, needs, and relationships in family and community to those of work life. The ecology of these relationships deserves to be explored both for the insights it will provide and for the opportunities to create constructive change.

I find all these compelling reasons for community psychologists to be interested in work and the relationship between work and community. But let me explore the possibilities in more detail. Let us first consider the workplace as a source of the psychological sense of community, and then turn our attention to the dynamic interplay and mutual influence or work life and community life. 


\section{THE WORKPLACE AND THE PSYCHOLOGICAL SENSE OF COMMUNITY}

Recently, Klein and D'Aunno (in press) have offered us a thoughtful and scholarly exploration of the ways in which the workplace can provide a psychological sense of community. They draw upon Sarason's original idea (Sarason, 1974, p.1) that the sense of community refers to the sense that one belongs in and is meaningfully a part of a larger collectivity. Klein and D'Aunno argue that "the psychological sense of community at work refers to a worker's sense of membership, participation, and identification with some work or work-related group, whether that work group is as small and concrete as the company softball team or as large and amorphous as the population of lawyers across the country" (p. 5).

Furthermore, they observe that the psychological sense of community at work has multiple referents, and that each of them may play a role in our own sense of belongingness. These referents include (a) the friendship network, (b) the functional work group of the organization, (c) the organization as a whole, (d) the job class or profession, and finally (e) the worksite itself. Each of these referents is a potentially potent source of the psychological sense of community. And it is worth noting that each also represents a different level of analysis. An understanding of the contribution of each of these referents will require cross-level analyses (D'Aunno \& Price, 1984) in a range of different settings.

But what are the possible sources of the psychological sense of community at work? Some of them are part of the job itself. To the degree that workers see the task as a whole and have an opportunity to work on many parts of it, one's identification with the task increases (Hackman \& Oldham, 1975). In jobs where there is considerable opportunity for interaction, the sense of community can be enhanced, and conversely, the lack of such opportunities can produce alienation and isolation (Cammann, Fichman, Jenkins, \& Klesh, 1983). But perhaps most of all, collaboration, interdependent work, participation in decision making, gains sharing, and even shared ownership are potential sources of the psychological sense of community (Klein, in press; Rosen, 1982). These are not merely labels on a social scientist's multidimensional model, they are real characteristics of real jobs. The sense of community and fulfillment that is possible can perhaps best be illustrated by an example. These are the words of the director of a small nonprofit bakery, Kay Stepkin:

We try to have a compromise between doing things efficiently and doing things in a human way. Our bread has to taste the same way every day, but you don't have to be machines. On a good day it's beautiful to be here. We have a good time and work hard and we're laughing .... I think a person can work as hard as he's capable, not only for others but for his own satisfaction . . . . Work is an essential part 
of being alive. Your work is your identity. It tells you who you are . . there's such a joy in doing work well. (Terkel, 1974, p. 612)

Kay Stepkin tells us how the psychological sense of community can emerge in the workplace in a way that no set of abstract dimensions can. Too often our preconceptions about the stressful or alienating aspects of work blind us to the possibilities and opportunities for community. And, of course, a sense of community itself is a source of social support to reduce or buffer stressful work demands (House, 1981), and to enrich and give new meaning to our lives.

\section{INFLUENCES FROM WORK TO COMMUNITY}

It is possible to create a psychological sense of community at work. But does the influence remain only there, or does it spread beyond the confines of the plant floor and the office walls? The evidence is compelling that work, family, and community cannot be thought of as separate worlds. But what is it that gets transmitted from work to community? How does the transmission happen? What is its impact?

The mechanisms of transmission from work to community are multiple. They depend on the experience of work itself (Hackman \& Oldham, 1975), the multiplexity of friendship and work ties (Gottlieb, 1981), and even the economic role of work organizations in the community as a whole (Buss, Redburn, \& Waldrun, 1983). Let us focus on the experience of work itself and its spillover to family and community.

Consider first the evidence for emotional spillover from work to family. Piotrkowski (1979) had conducted some of the pioneering work in this area. In a study of blue-collar families she found that boring, nondemanding work with little opportunity for control generated a pattern of withdrawal from family participation. Furthermore, demanding and conflict-ridden work situations, which were also characterized by little control, tended to generate a pattern of tense family interaction.

But it is not only emotional experiences that are transmitted from work to community. In a recent study, Piotrkowski and Katz (1982) examined the intriguing hypothesis that the occupational conditions of parents may produce indirect socialization effects on children's school behavior. Following a model initially developed by Kohn (1977), they examined three critical characteristics of the work life of mothers, the degree to which the mother's job provided her with autonomy in carrying out work tasks, the degree to which the mother's skills were fully utilized in the work task, and the extent to which the job placed heavy demands on the mother. They found that the academic behaviors of children were specifically affected by these work characteristics. For example, the greater the extent of the mother's own skills being used 
on the job, the higher the children's math achievement. While alternative explanations for these findings are always possible, the important lead they suggest is that the conditions of work can affect not only emotional relationships in the family, but also produce indirect effects on the psychological development of children.

There are other aspects of the work experience that may carry over into the family and community. Crouter (1984a) suggests that many U.S. firms are moving away from a traditional management system which involves segmented work and hierarchical organizational arrangements. They are moving instead toward participatory approaches in which employees are more involved in the company's decision-making and problem-solving processes. These "quality of work life" experiments (Lawler, 1982) were originally designed to enhance productivity and employee morale. But Crouter (1984a) argues that the experience of work with enhanced participation by workers may have other effects as well.

There are at least three important dimensions of increased participation in work that transform the workers' experience (Crouter, 1984a). First, the complexity of the work itself becomes greater as workers need a broader range of skills to accomplish all of the tasks presented to a work team. Second, increased participation also involves greater social interaction, more conjoint problem solving, and group decision making. And finally, workers' experience increases in their own autonomy and power in the context of their work group. Crouter's (1984a) intriguing thesis is that

\footnotetext{
Participative work settings serve as a context for the development of behavior and attitudes that manifest themselves in turn in other contexts, specifically the family and community. Participation enhances employees' psychological and social functioning in a way that makes them more effective as spouses, parents, and members of the community. (pg. 74)
}

Pateman (1970) and Staines (1980) suggest that the cognitive and behavioral skills learned in participatory work, both cognitive and behavioral, tend to generalize to family and community settings. Crouter's own research with workers in quality of work life settings has identified changes in the nature of the marital role, for example. Developing independent judgment and communication skills may transform the marital relationship sometimes in unexpected ways. Resources developed in the workplace become available at home. As one assembly worker noted, "I've learned how to fight more effectively with my husband. It has really helped! After all, your family is a kind of team" (Crouter, 1984a, p. 80).

But the parental role also appears to be enhanced. A machine operator observed, "I say things to may [8-year-old] daughter that I know are a result of the way we do things at work. I ask her, "What do you think about that?" 
or 'How would you handle this problem?' I tend to deal with her the way I deal with people at work. The logic is the same" (Crouter, 1984a, pp. 81-82).

Crouter (1984a) argues that community roles are also enhanced when participation is increased in the workplace. Job reform efforts in Sweden have provided us with a number of natural experiments in which it is possible to contrast workers in industries in which jobs became more active and involved with those which did not. Karasek (1978) has studied a longitudinal random sample of the Swedish work force and the evidence suggests that workers whose jobs became more passive also became more passive in their political and leisure activities, while workers with more active jobs became more active in the community context.

The findings are still fragmented and anecdotal but the implications are enormously important. If there are connections between the quality of work experience and the quality of life in family and community of the kind that I have described, then the positive and negative spillover from work to community life represents forces that no community psychologist can ignore. The work-community interface represents an ecological boundary zone of great potential influence. The evidence also suggests that work redesign to increase participation, originally aimed at increasing productivity and morale, may also have the possibility of strengthening family and community life.

\section{INFLUENCES FROM COMMUNITY TO WORK}

So far, I have argued that there are numerous avenues for creating a psychological sense of community at work with potential benefits both for workers and the work organization. I have also argued that the conditions of work, both those that are stressful and those that encourage participation, can spill over from the workplace to the family and community. As Kahn (1983) remarks, "If we wish seriously to improve life off the job, we must also attend to life at work - hours, schedules, and in the broadest sense of the word, activities" (p. 17). Perhaps it is not too much to suggest that community psychologists can influence the quality of life both at work and in the community through their efforts to understand and to influence the conditions of work.

But what about the influence in the other direction, from the community to the workplace? I suggest that we need at least to reconsider three things: (a) the current boundaries between work and community, (b) the allocation of work, and (c) its very definition. Let me summarize some research findings and then suggest the implications for the allocation, definition, and the boundary between work and the rest of our lives. 


\section{Boundaries}

Recently, Crouter (1984b) took seriously the suggestion that influences flow not only from work to community but from family and community to work. Her research involved detailed interviews with workers about their jobs and their family lives, and identified positive and negative instances of spillover from community and family to the workplace. Some of the most interesting and important findings had to do with striking differences between men and women to the extent in which they experienced negative spillover from home to work. There were no differences between nonparents in this regard, but fathers and mothers experienced different amounts of negative spillover. In fact, men experienced no difference whether they were parents or not, but mothers experienced relatively high levels of negative spillover and stress. Furthermore, this experience of stress was related not only to family and sex role but also to life-cycle characteristics. Mothers with preschool or latency-age children experienced the highest levels of negative spillover, but by the time their children reached adolescence or young adulthood, they differed not at all from fathers who experienced approximately the same low levels throughout the life cycle.

Other research supports these findings. Time studies on the allocation of leisure (Szalai, 1972) indicates that homemakers and working men employed outside the home enjoy approximately the same amount of leisure time, but employed women enjoy considerably less. People who work at both paid jobs and homemaking experience very little leisure and the combined burden falls most heavily on employed women. The consequences for family and community can be substantial. As Bronfenbrenner observes,

The crucial role of work in today's family life derives from what appears to be an especially distinctive feature of contemporary American society. From an evolutionary perspective, there are two kinds of activities that appear particularly salient for our species. The first is work; that is transforming our environment through using our heads and our hands. The second distinctive characteristic of Homo sapiens is the way in which we raise our young. To a greater extent than for any other living creatures, the capacity of human offspring to survive and develop depends on care and close association in activity with older members of the species.

To move from the general to the particular, at this point in human history, we in the United States have developed a pattern in which these two centrally fused human activities are often placed in conflict with each other. (Bronfenbrenner, 1981, p. $9 \& 10$ )

These and other similar findings suggest a reconsideration of the boundaries between work, family, and community. The boundaries can be physical or temporal. For example, the development of employer-sponsored childcare reflects the movement of domestic life into the workplace, a shift in boundaries (Phillips, 1984). Similarly, the capacity to take work home is enjoyed by many professionals but seldom extended to all of the jobs where it could be easily accomplished. 
The boundary between work, family and community which has been most discussed, of course, is temporal. Flexible work scheduling and maternal and paternal leaves have been recommended in the social policy literature (Kamerman \& Kingston, 1982), but considerably more talk than action has taken place thus far. Furthermore, these shifts in the boundary between community and work will not by themselves reduce some of the imbalances and strains that I have described. Reallocation of parental and sex-role responsibilities at home and at work are still necessary. Nevertheless, shifts in the temporal and geographical boundaries between community and work can provide the conditions for a more fulfilling family and community life.

\section{Allocation}

Let me now consider a number of other facts about the nature of work that set up forces for change. In our country approximately $10 \%$ of the labor force, or nearly 10 million people, are actively looking for work. Among youth, and black youth in particular, the unemployment figures approach $50 \%$ and figures for discouraged workers are considerably higher. Furthermore, we appear to be running out of work in modern industrialized societies while the labor force continues to grow (Kahn, 1983). The number of 40-hour-a-week paid jobs that produce goods or services appears to be shrinking, even in times of economic expansion. In addition, people who are working, in many cases, feel that they have too much work and want less. According to Quinn and Staines (1979), about $12 \%$ of all employed men and women would like to work different or fewer days per week, and their primary reason for this is the interference of work with family life.

Only now are experiments beginning to develop that can respond to the corrosive experience of unemployment. At Michigan, our Michigan Prevention Research Center is developing and testing a program designed to: (a) help unemployed workers more effectively identify helping- and job-related resources in their community, (b) better identify their own skills and strengths that can be transformed into assets in the job market, and (c) reduce the length of unemployment, a major risk factor for demoralization, depression, family conflict, and alcohol abuse (Price, 1984b).

But while programs like these can have some impact, other changes in the allocation of work are needed. Work sharing (Best, 1981) is one example. While this can come in many forms, it represents a reallocation of work in ways that do not divide the world into have's and have not's, the dependent and the privileged. These experiments in the restructuring of work represent rare opportunities for community psychologists.

Still other possibilities exist to consider the interconnections between unions, workers, companies, and human service agencies in the community 
(Price \& D'Aunno, 1983) in the face of work force reductions. An examination of the nature of actual and potential resource exchange among these groups can reveal interdependence that can form the basis of more effective community responses to plant closings.

\section{Definition}

A last opportunity for community psychologists to examine the relationship between community and work has to do with the definition of work itself. Full-time paid jobs do not nearly represent the full range of productive activities through the life course. We should "abandon in our national statistics and in our thinking the dangerous pretense that life consists of paid employment and a great undifferentiated residual" (Kahn, 1983, p. 2). In addition to paid employment, we should be advocating and nurturing voluntary organizational activity and mutual help in which services are exchanged as legitimate and important forms of productive behavior.

These are forms of productive behavior that community psychologists have always believed are critical to the vitality of the community. We have an opportunity to affirm the importance of these activities to create new opportunities in which mutual help and work in voluntary organizations can enrich the lives both of those who are beneficiaries of the work and those who engage in it.

\section{CONCLUSION}

I have argued that research and action in the world of work can be a central concern and a major opportunity for community psychologists. Work is central to well being and identity. It is an arena of rapid and turbulent social change where our values are expressed and lived out. Furthermore, work is not a separate life domain, but interpenetrates family and community life. Work is a source of the psychological sense of community and can be made more so. Experiences at work can spill over to family and community and vice versa. Recognizing the myriad paths of this interdependence is an ecological insight that has the possibility of real consequences for well being in our communities. We have only to act on our insight.

\section{REFERENCES}

Best, F. Work sharing: Issues, policy options, and prospects. Upjohn Institute for Employment Research, Kalamazoo, MI: 1981. 
Bronfenbrenner, U. The ecology of human development: Experiments by nature and design. Cambridge, MA: Harvard University Press, 1979.

Bronfenbrenner, U. New images of children, families and America. Television \& Children, 1981-1982, Fall/Winter, 3-15.

Buss, T. F., Redburn, F. S., \& Waldron, J. Mass unemployment: Plant closings and community mental health. Beverly Hills, CA: Sage Publications, 1983.

Cammann, C., Fichman, M., Jenkins, G. D., Jr., \& Klesh, J. R. Assessing the attitudes and perceptions of organizational members. In S. Seashore (Ed.), Assessing organizational change. New York: Wiley, 1983.

Crouter, A. C. Participative work as an influence on human development. Journal of Applied Developmental Psychology, 1984a, 5, 71-90.

Crouter, A. C. Spillover from family to work: The neglected side of the work-family interface. Human Relations, 1984b, 37(6), 425-442.

D'Aunno, T. A., \& Price, R. H. The context of community research. In K. Heller, R. H. Price, S. Reinharz, S. Riger, \& A. Wandersman (Eds.), Psychology and community change. Homewood, IL: The Dorsey Press, 1984.

Gottlieb, B. H. (Ed.). Social networks and social support. Beverly Hills, CA: Sage Publications, 1981.

Hackman, J. R., \& Oldham, G. R. Development of the job diagnostic survey. Journal of Applied Psychology, 1975, 60, 159-170.

House, J. S. Work stress and social support. Reading, MA: Addison-Wesley, 1981.

Kahn, R. L. Work and health. New York: Wiley, 198I.

Kahn, R. L. Productive behavior through the life course. Paper presented at the Mohonk Conference on Human Resource Implications of an Aging Workforce, Carnegie Corporation of New York, 1983, September.

Kamerman, S. B., \& Hayes, C. D. (Eds.). Families that work: Children in a changing world. Washington, D.C.: National Academy Press, 1982.

Kamerman, S. B., \& Kingston, P. Employer responses to the family responsibilities of employees. In S. B. Kamerman \& C. D. Hayes (Eds.), Families that work: Children in a changing world. Washington, D.C.: National Academy of Sciences, 1982.

Karasek, R. Job socialization: A longitudinal study of work, political and leisure activity. Revised working Paper No. 59. Stockholm: Institute for Social Research, 1978.

Klein, K. J. The effects of employee stock ownership on employees' job satisfaction, organizational commitment, and well-being. (Doctoral dissertation, University of Texas, Austin, 1984). Dissertation Abstracts International, In press.

Klein, K. J., \& D'Aunno, T. A. The psychological sense of community in the workplace. Journal of Community Psychology, in press.

Kohn, M. L. Class and conformity, a study in values (2nd ed.). Chicago: University of Chicago Press, 1977.

Lawler, E. E. Strategies for improving the quality of work life. American Psychologist, 1982, $37,486-493$.

Pateman, C. Participation and democratic theory. London: Cambridge University Press, 1970.

Phillips, D. Day care: Promoting collaboration between research and policymaking. Journal of Applied Developmental Psychology, 1984, 5, 91-113.

Piotrkowski, C. S. Work and the family system. New York: Macmillan, 1979.

Piotrkowski, C. S., \& Katz, M. H. Indirect socialization of children: The effects of mothers' jobs on academic behaviors. Child Developmet, 1982, 53, 1520-1529.

Piotrkowski, C. S., \& Katz, M. H. Work experience and family relations among working-class and lower middle-class families. In H. Z. Lopata, \& J. H. Pleck (Eds.), Research in the interweave of social roles, Vol. 3: Families and jobs. Greenwich, CT: JAI Press, 1982.

Price, R. H. The effect of long term unemployment on children, youth and families: Policy options. Testimony submitted to the Select Committee on Children, Youth and Families, U.S. House of Representatives, 1984a, March.

Price, R. H. The Michigan Prevention Research Center as an organization linking research and service to the unemployed. Testimony presented to the National Commission on Unemployment and Mental Health, National Mental Health Association, 1984b, June. 
Price, R. H. Research on mental health problems in the worksite: $A$ state of the art review. Paper prepared for the First Business and Industry Roundtable on Alcohol, Drug Abuse and Mental Disorders at the worksite, The Alcohol, Drug Abuse and Mental Health Administration, Washington, D.C., 1984c, September 20-21.

Price, R. H., \& D'Aunno, T. Managing work force reduction. Human Resource Management, $1983,22(4), 413-430$.

Quinn, R. P., \& Staines, G. L. The 1977 quality of employment survey. Institute for Social Research. Ann Arbor, MI: 1979.

Robey, B., \& Russell, C. A portrait of the American worker. American Demographics, 1984, March, 17-21.

Rosen, C. M. Employee ownership: Issues, resources, and legislation. Arlington, VA: National Center for Employee Ownership, 1982.

Sarason, S. B. The psychological sense of community. San Francisco: Jossey-Bass, 1974.

Staines, G. L. Spillover versus compensation: A review of the literature on the relationship between work and nonwork. Human Relations, 1980, 33(2), 111-129.

Szalai, A. The use of time. Mouton: The Hague, 1972, 131.

Terkel, S. Working (rev. ed.). New York: Avon Books, 1974. 